\title{
Supporting Accessibility in Higher Education Information Systems: a 2016 Update
}

\author{
Reis, A. ${ }^{1}$, Martins, P. ${ }^{1}$, Borges, J. $^{2}$, Sousa, A. ${ }^{1}$, Rocha, T. ${ }^{1}$, Barroso, J. ${ }^{1}$ \\ ${ }^{1}$ INESC TEC and University of Trás-os-Montes e \\ Alto Douro, Vila Real, Portugal \\ \{ars, pmartins, andresousa, trocha, jbarroso\} @utad.pt \\ ${ }^{2}$ University of Trás-os-Montes e Alto Douro, Vila Real, Portugal \\ jborges@utad.pt
}

Keywords: Higher education institutions; Accessibility; W3C; Moodle;

DSpace.

\begin{abstract}
Higher Education Institutions (HEIs) have come a long way on the usage of Information Systems (IS) at the several phases of the execution of their business plan. These organizations are very peculiar in the sense that most of the IS technologies have been developed as a consequence of the research work of the HEIs, positioning them as creators and as consumers of IS technologies. In fact, a considerable part of the IS products, currently available for the education sector, was initially created in a HEI as an in-house development. For these reason, the adoption of IS technologies by HEIs has followed two distinct paths: the in-house creation, previously described; and a current market adoption, similarly to most other companies IS adoption.

Up to 2013 the IS applications for HEIs was mostly provided as web applications running on the HEI local datacenters and devoted to some specific phases of the HEI business plan. Currently, in 2016, this scenario has evolved in two ways: i) to a wider range of type of applications, including: the old type of web application; new mobile applications; and new web application, running on the cloud and used as a service. ii) to a more extended support coverage regarding the HEI business model phases, i.e., there are more IS applications supporting more aspects of the HEIs' activities.

In 2013, it was published a study regarding the accessibility support in HEI IS applications and related user practices. Due to the advances in IS technologies and their adoption by HEIs, it is now time to update this perspective on accessibility and HEIs IS, in order to assess how the progresses on IS applications used in HEIs have dealt with the accessibility concerns. The study updates the IS accessibility features as well as the new systems and new types of systems currently in use.
\end{abstract}

adfa, p. 1, 2011.

(C) Springer-Verlag Berlin Heidelberg 2011 


\section{Introduction}

In our previous work [1-2], we focused on the software systems used by the higher education institutions (HEIs) and how those systems coped with the accessibility requirements. The analysis was carried out by using the University of Trás-os-Montes and Alto Douro (UTAD) as a case study. UTAD, like most HEIs, has its business model and activities supported by several information systems (IS), most of which are used to produce and support content, e.g., the moodle learning management system (LMS), Microsoft sharepoint, joomla, wordpress, etc. We used a semi-automatic tool, the Total Validator [3], and did a general assessment of the sites, together with a bibliographic assessment of the features provided by each software system, used to support the sites. In our conclusions, we stressed the fact that all of these systems have the necessary features to create and support accessible content, thus, leaving to the content designers and creators the ultimate responsibility to address the accessibility issues in their content related practices. A proposal was issued regarding the adoption of rules to regulate the design and creation of content in order to assure some degree of accessibility compliance.

In this 2016 update, we opted to do an automatic analysis of the current sites, using the Sortsite tool [4]. We assumed that the software systems have the necessary features to comply with the accessibility issues and the assessment results are mainly a consequence of the content creators' practices.

\section{Accessibility evaluation}

The evaluation was executed using the SortSite (version 5) automatic tool, which was selected due to its advanced analysis features, providing a deep analysis, such as, general errors' evaluation, accessibility and usability guidelines compliance, etc. The usage of automatic tools has some limitations, but Sortsite can be used to produce a reliable overall assessment [4-5].

The evaluation was focused on three general areas:

- Errors, in which were verified: server configuration; blocked hyperlinks; page limits; user defined errors; HTTP code status; and script errors.

- Accessibility compliance regarding the Electronic and Information Technology Accessibility Standards (Section 508) [6] and the Web Content Accessibility Guidelines 2.0 (WCAG 2.0) [7].

- Usability, regarding: guidelines of legibility; guidelines according to the research in web design and usability, and to Usability.gov [8] and W3C usability guidelines [9].

The following sites, including all their pages and elements, were evaluated:

1. Teaching and learning support system (SIDE) [10-12].

2. Research scholarships management [13].

3. Pedagogical surveys.

4. Digital repository [14-16]. 
5. On-line certificates [17].

6. Online Campus [18].

7. Document management [19].

8. Students registry [20].

9. E-learning management system (Moodle) [21-23].

10. Intranet [24-26].

\subsection{The teaching and learning support system (SIDE)}

The SIDE system (at http://side.utad.pt) is the IS platform that supports the teaching and learning related processes, including most of the academic tasks and activities, performed by professors and students, at UTAD. The SIDE platform provides: courses' content publication; exams scheduling; students' attendance registration; coursework electronic submission; etc. Table 1 summarizes this item evaluation report.

A total of 756 pages were evaluated, comprising the following elements: $240 \mathrm{HTML}$ pages; 237 GIF images; 7 PNG images; 4 CSS sheets; 3 Javascript scripts; 1 PDF document; 32 external links.

Table 1 - Accessibility assessment of the teaching and learning support system (SIDE).

\begin{tabular}{|c|c|}
\hline Problems & $\begin{array}{l}\text { Sortsite } \\
\text { Classification }\end{array}$ \\
\hline 233 pages have quality problems. & Better than average \\
\hline 9 pages have errors, such as "broken links" and others. & Better than average \\
\hline $\begin{array}{l}232 \text { pages have accessibility problems: } \\
\text { Priority } 1 \text { (A), } 17 \text { errors; } \\
\text { Priority } 2 \text { (AA), } 2 \text { errors; } \\
\text { Priority } 3 \text { (AAA), } 2 \text { errors. }\end{array}$ & Worse than average \\
\hline 223 pages have specific browser compatibility problems. & Worse than average \\
\hline No pages with privacy problems. & Better than average \\
\hline 202 pages have search engines related problems. & Better than average \\
\hline $\begin{array}{l}229 \text { pages have compliance problems with the W3C } \\
\text { standards. }\end{array}$ & Worse than average \\
\hline $\begin{array}{l}231 \text { pages have usability problems: } \\
\text { Priority 1, } 0 \text { errors; } \\
\text { Priority 2, } 6 \text { errors; } \\
\text { Priority } 3,2 \text { errors; } \\
\text { Priority 4, } 0 \text { errors. }\end{array}$ & Better than average \\
\hline
\end{tabular}

\subsection{Research Scholarships Management System}

The Research Scholarships Management System (at www.campus.utad.pt/bolsasinvestigacao/gestao) fully supports the processes related to the UTAD's scholarships, in all 
their phases, including announcements and submissions. Table 2 summarizes this item evaluation report.

A total of 53 pages were evaluated, comprising the following elements: 13 HTML pages; 15 PNG images; 23 CSS sheets; 7 scripts Javascript; 5 external links.

Table 2 - Accessibility assessment of the Research Scholarships Management System.

\begin{tabular}{|c|c|}
\hline Problems & $\begin{array}{l}\text { Sortsite } \\
\text { Classification }\end{array}$ \\
\hline 29 pages have quality problems. & Worse than average \\
\hline 2 pages have errors, such as "broken links" and others. & Better than average \\
\hline $\begin{array}{l}2 \text { pages have accessibility problems: } \\
\text { Priority } 1 \text { (A), } 6 \text { errors; } \\
\text { Priority } 2 \text { (AA), } 3 \text { errors; } \\
\text { Priority } 3 \text { (AAA), } 2 \text { errors. }\end{array}$ & Better than average \\
\hline 12 pages have specific browser compatibility problems. & Worse than average \\
\hline 1 page has privacy problems. & Better than average \\
\hline 2 pages have search engines related problems. & Better than average \\
\hline $\begin{array}{l}9 \text { pages have compliance problems with the W3C stand- } \\
\text { ards. }\end{array}$ & Better than average \\
\hline $\begin{array}{l}13 \text { pages have usability problems: } \\
\text { Priority } 1,0 \text { errors; } \\
\text { Priority } 2,5 \text { errors; } \\
\text { Priority } 3,1 \text { errors; } \\
\text { Priority } 4,1 \text { errors. }\end{array}$ & Better than average \\
\hline
\end{tabular}

\subsection{Pedagogical Surveys}

The Surveys System (at http://www.campus.utad.pt/questionarios/Account/Login_LDAP) is a survey tool, designed to support the processes of self-evaluation and continuous improvement of teaching and learning. It is used in all the courses, by all the students, in order to assess how the courses are being delivered. Table 3 summarizes this item evaluation report.

A total of 45 pages were evaluated, comprising the following elements: 2 HTML pages; 6 JPEG images; 9 PNG images; 6 CSS sheets; 8 Javascript scripts; 7 external links.

Table 3 - Accessibility assessment of the Pedagogical Surveys System.

\begin{tabular}{ll}
\hline \hline Problems & $\begin{array}{l}\text { Sortsite } \\
\text { Classification }\end{array}$ \\
\hline 7 pages have quality problems. & Better than average \\
\hline 2 pages have errors, such as "broken links" and others. & Better than average \\
\hline 4 pages have accessibility problems: & Better than average \\
\hline \hline
\end{tabular}


Priority 1 (A), 6 errors;

Priority 2 (AA), 3 errors;

Priority 3 (AAA), 3 errors.

\begin{tabular}{ll}
\hline 3 pages have specific browser compatibility problems. & Better than average \\
\hline 2 pages have privacy problems. & Better than average \\
\hline 3 pages have search engines related problems. & Better than average \\
\hline 5 pages have compliance problems with the W3C stand- & Better than average \\
ards. & \\
\hline $\begin{array}{l}3 \text { pages have usability problems: } \\
\text { Priority 1, 1 errors; }\end{array}$ & Better than average \\
$\begin{array}{l}\text { Priority 2, } 3 \text { errors; } 3,1 \text { errors; } \\
\text { Priority 4, errors. }\end{array}$ & \\
\hline \hline
\end{tabular}

\subsection{Digital Scientific Repository}

The Scientific Repository (at http://repositorio.utad.pt) is a DSPACE based system [23], built in order to store, preserve and publish the scientific and intellectual production of the university. Table 4 summarizes this item evaluation report.

A total of 14656 pages were evaluated, comprising the following elements: 6928 HTML pages; 40 GIF images; 36 PNG images; 378 JPG images; 11 CSS sheets; 29 Javascript scripts; 306 PDF documents; 3962 feeds; 2202 external links.

Table 4 - Accessibility assessment of the Digital Scientific Repository.

\begin{tabular}{|c|c|}
\hline Problems & $\begin{array}{l}\text { Sortsite } \\
\text { Classification } \\
\end{array}$ \\
\hline 71567 pages have quality problems. & Worse than average \\
\hline 6831 pages have errors, such as "broken links" and others. & Worse than average \\
\hline $\begin{array}{l}7129 \text { pages have accessibility problems: } \\
\text { Priority } 1 \text { (A), } 18 \text { errors; } \\
\text { Priority } 2 \text { (AA), } 3 \text { errors; } \\
\text { Priority } 3 \text { (AAA), } 5 \text { errors. }\end{array}$ & Worse than average \\
\hline 81 pages have specific browser compatibility problems. & Better than average \\
\hline 6829 pages have privacy problems. & Worse than average \\
\hline 6827 pages have search engines related problems. & Worse than average \\
\hline $\begin{array}{l}1796 \text { pages have compliance problems with the W3C } \\
\text { standards. }\end{array}$ & Better than average \\
\hline $\begin{array}{l}6838 \text { pages have usability problems: } \\
\text { Priority } 1,1 \text { errors; } \\
\text { Priority } 2,3 \text { errors; } \\
\text { Priority } 3,1 \text { errors; } \\
\text { Priority } 4,1 \text { errors. }\end{array}$ & Worse than average \\
\hline
\end{tabular}




\subsection{On-line certificates system}

The certificates system (at http://certidao.utad.pt) is a site used by the students to access their academic certificates, e.g., course registration, degree conclusion, etc. Table 5 summarizes this item evaluation report.

A total of 76 pages were evaluated, comprising the following elements: 2 HTML pages; 2 ASPX pages; 11 GIF images; 8 PNG images; 3 JPG images; 9 CSS sheets; 10 Javascript scripts; 1 PDF documents; 6 external links.

Table 5 - Accessibility assessment of the on-line certificates system.

\begin{tabular}{ll}
\hline \hline Problems & $\begin{array}{l}\text { Sortsite } \\
\text { Classification }\end{array}$ \\
\hline 17 pages have quality problems. & Better than average \\
\hline 7 pages have errors, such as "broken links" and others. & Worse than average \\
\hline $\begin{array}{l}11 \text { pages have accessibility problems: } \\
\text { Priority 1 (A), 14 errors; }\end{array}$ & Better than average \\
$\begin{array}{l}\text { Priority 2 (AA), } 3 \text { errors; } \\
\text { Priority 3 (AAA), } 4 \text { errors. }\end{array}$ & \\
\hline 7 pages have specific browser compatibility problems. & Better than average \\
\hline No pages with privacy problems. & Better than average \\
\hline 7 pages have search engines related problems. & Better than average \\
\hline 12 pages have compliance problems with the W3C stand- & Better than average \\
ards. & \\
\hline 10 pages have usability problems: & Worse than average \\
$\begin{array}{l}\text { Priority 1, 2 errors; } 2,7 \text { errors; } \\
\text { Priority 3, } 1 \text { errors; }\end{array}$ & \\
\hline \hline
\end{tabular}

\subsection{Campus Online site}

The Campus Online site (at http://www.campus.utad.pt) is a web portal to publish academia related information to students. Table 6 summarizes this item evaluation report.

A total of 412 pages were evaluated, comprising the following elements: 97 HTML pages; 15 GIF images; 86 PNG images; 1 JPG images; 37 CSS sheets; 57 Javascript scripts; 2 PDF documents; 139 external links.

Table 6 - Accessibility assessment of the Online Campus site.

\begin{tabular}{ll}
\hline \hline Problems & $\begin{array}{l}\text { Sortsite } \\
\text { Classification }\end{array}$ \\
\hline 123 pages have quality problems. & Better than average \\
\hline 37 pages have errors, such as "broken links" and others. & Worse than average \\
\hline 59 pages have accessibility problems: & Better than average \\
\hline \hline
\end{tabular}


Priority 1 (A), 10 errors;

Priority 2 (AA), 3 errors;

Priority 3 (AAA), 4 errors.

70 pages have specific browser compatibility problems. Worse than average

No pages with privacy problems. Better than average

47 pages have search engines related problems. Better than average

58 pages have compliance problems with the $\mathrm{W} 3 \mathrm{C}$ stand- Better than average ards.

99 pages have usability problems:

Priority 1,0 errors:

Priority 2, 5 errors; $\quad$ Worse than average

Priority 3, 3 errors;

Priority 4, 0 errors;

\subsection{GESDOC document management system}

The GESDOC (at http://gesdoc.utad.pt) is a process workflow system that electronically supports some of the organization wide administrative process. Table 7 summarizes this item evaluation report.

A total of 43 pages were evaluated, comprising the following elements: 2 HTML pages; 1 ASPX page; 5 PNG images; 5 JPG images; 5 CSS sheets; 5 Javascript scripts; 9 PDF documents; 6 external links.

Table 7 - Accessibility assessment of the document management system.

\begin{tabular}{|c|c|}
\hline Problems & $\begin{array}{l}\text { Sortsite } \\
\text { Classification }\end{array}$ \\
\hline 17 pages have quality problems. & Better than average \\
\hline 3 pages have errors, such as "broken links" and others. & Worse than average \\
\hline $\begin{array}{l}13 \text { pages have accessibility problems: } \\
\text { Priority } 1 \text { (A), } 11 \text { errors; } \\
\text { Priority } 2 \text { (AA), } 3 \text { errors; } \\
\text { Priority } 3 \text { (AAA), } 3 \text { errors. }\end{array}$ & Worse than average \\
\hline 4 pages have specific browser compatibility problems. & Better than average \\
\hline 1 page has privacy problems. & Better than average \\
\hline 2 pages have search engines related problems. & Better than average \\
\hline $\begin{array}{l}4 \text { pages have compliance problems with the W3C stand- } \\
\text { ards. }\end{array}$ & Better than average \\
\hline $\begin{array}{l}5 \text { pages have usability problems: } \\
\text { Priority 1, } 0 \text { errors; } \\
\text { Priority 2, } 5 \text { errors; } \\
\text { Priority } 3,1 \text { errors; } \\
\text { Priority 4, } 1 \text { errors; }\end{array}$ & Better than average \\
\hline
\end{tabular}




\section{$2.8 \quad$ Students registry}

The students registry (at http://www.campus.utad.pt/registoacademico) is a web application that provides the interface features to access the full records of the students, including, course plans, fees, grades, and other additional documents. Table 8 summarizes this item evaluation report.

A total of 425 pages were evaluated, comprising the following elements: 99 HTML pages; 15 GIF images; 89 PNG images; 1 JPG image; 40 CSS sheets; 59 Javascript scripts; 2 PDF documents; 142 external links.

Table 8 - Accessibility assessment of the Students Registry System.

\begin{tabular}{|c|c|}
\hline Problems & $\begin{array}{l}\text { Sortsite } \\
\text { Classification } \\
\end{array}$ \\
\hline 128 pages have quality problems. & Better than average \\
\hline 37 pages have errors, such as "broken links" and others. & Worse than average \\
\hline $\begin{array}{l}62 \text { pages have accessibility problems: } \\
\text { Priority } 1 \text { (A), } 10 \text { errors; } \\
\text { Priority } 2 \text { (AA), } 3 \text { errors; } \\
\text { Priority } 3 \text { (AAA), } 4 \text { errors. } \\
\end{array}$ & Better than average \\
\hline 72 pages have specific browser compatibility problems. & Worse than average \\
\hline No page has privacy problems. & Better than average \\
\hline 49 pages have search engines related problems. & Better than average \\
\hline $\begin{array}{l}60 \text { pages have compliance problems with the W3C stand- } \\
\text { ards. }\end{array}$ & Better than average \\
\hline $\begin{array}{l}102 \text { pages have usability problems: } \\
\text { Priority } 1,0 \text { errors; } \\
\text { Priority 2, } 6 \text { errors; } \\
\text { Priority } 3,4 \text { errors; } \\
\text { Priority 4, } 0 \text { errors; }\end{array}$ & Better than average \\
\hline
\end{tabular}

\subsection{E-learning management system (Moodle)}

The e-learning management system (at http://moodle.utad.pt) is a Moodle based platform [24], used, together with SIDE, to support the leaning and teaching activities. Table 9 summarizes this item evaluation report.

A total of 855 pages were evaluated, comprising the following elements: 56 HTML pages; 708 PHP pages; 15 PNG images; 1 JPG image; 10 CSS sheets; 23 Javascript scripts; 21 external links.

Table 9 - Accessibility assessment of the e-learning management system.

\begin{tabular}{ll}
\hline \hline \multirow{2}{*}{ Problems } & Sortsite \\
& Classification \\
\hline
\end{tabular}




\begin{tabular}{ll}
\hline 772 pages have quality problems. & Worse than average \\
\hline 488 pages have errors, such as "broken links" and others. & Worse than average \\
\hline 712 pages have accessibility problems: & \\
$\begin{array}{l}\text { Priority } 1 \text { (A), } 6 \text { errors; } \\
\text { Priority 2 (AA), 5 errors; }\end{array}$ & Worse than average \\
Priority 3 (AAA), 3 errors. & \\
\hline 765 pages have specific browser compatibility problems. & Worse than average \\
\hline No page has privacy problems. & Better than average \\
\hline 243 pages have search engines related problems. & Worse than average \\
\hline $\begin{array}{l}184 \text { pages have compliance problems with the W3C } \\
\text { standards. }\end{array}$ & Better than average \\
\hline 76 pages have usability problems: & \\
$\begin{array}{l}\text { Priority 1, } 0 \text { errors; } \\
\text { Priority 2, } 4 \text { errors; }\end{array}$ & \\
Priority 3, 4 errors; & Worse than average \\
Priority 4, 0 errors; & \\
\hline \hline
\end{tabular}

\subsection{Intranet portal}

The intranet portal (at http://www.intra.utad.pt) is the university's internal platform to store and share information and worflows, based on Microsoft Sharepoint [25]. Table 10 summarizes this item evaluation report.

A total of 6035 pages were evaluated, comprising the following elements: 49 HTML pages; 4144 ASPX pages; 55 GIF images; 74 PNG images; 19 JPG image; 19 CSS sheets; 15 Javascript scripts; 25 external links.

Table 10 - Accessibility assessment of the intranet portal.

\begin{tabular}{|c|c|}
\hline Problems & $\begin{array}{l}\text { Sortsite } \\
\text { Classification }\end{array}$ \\
\hline 6035 pages have quality problems. & Worse than average \\
\hline 2028 pages have errors, such as "broken links" and others. & Worse than average \\
\hline $\begin{array}{l}3952 \text { pages have accessibility problems: } \\
\text { Priority } 1 \text { (A), } 29 \text { errors; } \\
\text { Priority } 2 \text { (AA), } 5 \text { errors; } \\
\text { Priority } 3 \text { (AAA), } 2 \text { errors. }\end{array}$ & Worse than average \\
\hline 2093 pages have specific browser compatibility problems. & Worse than average \\
\hline 1 page has privacy problems. & Better than average \\
\hline 2089 pages have search engines related problems. & Worse than average \\
\hline $\begin{array}{l}2089 \text { pages have compliance problems with the W3C } \\
\text { standards. }\end{array}$ & Worse than average \\
\hline $\begin{array}{l}4101 \text { pages have usability problems: } \\
\text { Priority } 1,1 \text { errors; }\end{array}$ & Worse than average \\
\hline
\end{tabular}


Priority 2, 7 errors;

Priority 3, 6 errors;

Priority 4, 1 errors;

Priority 5, 1 errors;

\section{Conclusion}

The sites collection is heterogeneous, in regard to their size, usage, content, and life time. So, as expected, there are very different evaluation results, from which several conclusions can be drawn.

The sites with the poorest performance are those in which the user (or user community) can create content. The intranet portal or the elearning portal are good examples, on which the users can create content, sometimes with a short life span, e.g., an event or an academic year. Soon after the content creation, the pages will not be maintained, thus resulting in broken links, future browser compatibility issues, etc. As the sites get older, without proper content maintenance, this problem will grow critical.

The sites designed as web application for specific purposes, in which the content form and the user interface are predetermined in the development phase, have generally good performance. Two examples are the Students registry and Gesdoc, in which the content is retrieved from databases and later rendered by the system, prior to being delivered to the user. Is this cases, the accessibly issues are well tackled by the software designers and programmers.

The three sites requiring urgent attention are: repository, elearning, and intranet. In this cases, the platforms supporting the sites (DSpace, Moodle, and SharePoint) are widely used for their specific purposes and have the necessary accessibility features built in. It is up to the integrator or final user to have the correct content creation practices in order to incorporate the accessibility features.

In terms of future actions, four proposals, based on this conclusions:

1. To implement a continuous monitoring of the sites accessibility (a periodically assessment should be scheduled) with a periodic report regarding the accessibility compliance of each content creator.

2. To edit a content creation guideline, including an accessibility compliance section.

3 . To implement a content maintenance schedule or program in order to remove outof-date content.

4. To develop further accessibility compliance actions, including manually assessments, focused on specific content and use cases.

\section{Acknowledgements}

Part of this work was financed by the FCT - Fundação para a Ciência e a Tecnologia (Portuguese Foundation for Science and Technology) research grant SFRH/BD/87259/2012. 


\section{References}

1. Arsénio Reis, João Barroso, Ramiro Gonçalves: Supporting Accessibility in Higher Education Information Systems. Proceedings of the 7th international conference on Universal Access in Human-Computer Interaction: applications and services for quality of life - Volume Part III; 07/2013, DOI:10.1007/978-3-642-39194-1_29.

2. Arsenio Reis, Barroso J, Bulas-Cruz J, Cunha J F: Entrepreneurship for IS development in the non-classic context. EUNIS'2006 - IS INFORMATION TECHNOLOGY SHAPING THE FUTURE OF HIGHER EDUCATION?, Tartu, Estonia; 06/2006

3. Validator, T. (2009). Total Validator. Internet: http://www. totalvalidator.com.

4. Vigo, M., Brown, J., \& Conway, V. (2013, May). Benchmarking web accessibility evaluation tools: measuring the harm of sole reliance on automated tests. In Proceedings of the 10th International Cross-Disciplinary Conference on Web Accessibility (p. 1). ACM.

5. Arsénio Reis, et al: International Conference on Technology and Innovation in Sports, Health and Wellbeing (TISHW): Vila Real, Portugal. 01-03 December 2016. 02/2017; 9(S1)., DOI:10.1186/s13102-017-0068-y.

6. Access-Board, US (2000). Section 508 Standards for Electronic and Information Technology. Internet: https://www.access-board.gov/guidelines-and-standards/communicationsand-it/about-the-section-508-standards/section-508-standards.

7. World Wide Web Consortium. (2008). Web content accessibility guidelines (WCAG) 2.0.

8. U.S. Dept. of Health and Human Services. The Research-Based Web Design \& Usability Guidelines, Enlarged/Expanded edition. Washington: U.S. Government Printing Office, 2006.

9. Matera, M., Rizzo, F., \& Carughi, G. T. (2006). Web usability: Principles and evaluation methods. In Web engineering (pp. 143-180). Springer Berlin Heidelberg.

10. Sistema de Informação de Apoio ao Ensino. (2017). Retrieved from http://side.utad.pt.

11. Luis Barbosa, Paulo Alves, Arsénio Reis, João Barroso: SIDE: Teaching Support Information System. Eunis 2011 Conference - Maintaining a Sustainable Future for IT in Higher Education, Dublin, Ireland; 01/2011.

12. Arsénio Monteiro Reis, Rio-Costa 15. A., Santos J., Borges J., Vasconcelos A., Barroso J., Bulas-Cruz J., Rodrigues F.: Providing Lifetime Services to Students. EUNIS International Conference 2009 "IT: Key of the European Space of Knowledge", Santiago de Compostela, Spain; 01/2009.

13. Research Scholarships Management. (2017). Retrieved from www.campus.utad.pt/bolsasinvestigacao/gestao.

14. Repositório Cientifico Digital. (2017). Retrieved from http://repositorio.utad.pt.

15. Jorge Santos, António Costa, Jorge Borges, Arsénio Reis, João Barroso, José Bulas-Cruz: Universidade de Trás-os-Montes e Alto Douro - Digital Scientific Repository - A Case Study. EUNIS'2007, Grenoble, France; 06/2007.

16. DSpace project. (2017). Retrieved from http://www.dspace.org.

17. On-line certificates. (2017). Retrieved from http://certidao.utad.pt.

18. Campus Online. (2017). Retrieved from http://www.campus.utad.pt.

19. Document management. (2017). Retrieved from http://gesdoc.utad.pt.

20. Students' registry. (2017). Retrieved from http://www.campus.utad.pt/registoacademico.

21. Moodle. (2017). Retrieved from http://www.moodle.org.

22. E-learning management system. (2017). Retrieved from moodle.utad.pt.

23. Arsénio Monteiro Reis, A. Costa, J. Barroso, J. Borges, A. Reis, A. Vasconcelos, Ramiro Gonçalves: The Univeristy of Trás-os-Montes and Alto Douro E-Learning Shared Federated 
Services - A Project Report. Eunis 2011 Conference - Maintaining a Sustainable Future for IT in Higher Education, Dublin, Ireland; 01/2011UTAD (2017).

24. Portal Intranet. (2017). Retrieved from http://intranet.utad.pt.

25. Jorge Santos, António Costa, Arsénio Reis, João Barroso, José Bulas-Cruz, Jorge Borges: Intranet Portal for a University Services - A Case Study. EUNIS'2007, Grenoble, France; 06/2007.

26. Microsoft Sharepoint. (2017). Retrieved from https://products.office.com/pt-pt/sharepoint/. 